\title{
Design Technology of Irrigation and Drainage Engineering in Hollow Villages in Hilly Mountains
}

\author{
Zhang Lu \\ ${ }^{1}$ Shaanxi Provincial Land Engineering Construction Group, Co., Ltd, Xi'an 710075, \\ China \\ ${ }^{2}$ Institute of Land Engineering and Technology, Shaanxi Provincial Land Engineering \\ Construction Group Co., Ltd. Xi'an 710021, China \\ ${ }^{3}$ Key Laboratory of Degraded and Unused Land Consolidation Engineering, the \\ ministry of Natural Resources, Xi'an 710021, China \\ luluqiaofeng@126.com
}

\begin{abstract}
As a large agricultural country, China has a large population and a small population. Not only is the quantity and quality of cultivated land scarce, the reserve cultivated land resources are insufficient and the development is difficult. Under such basic national conditions, a large number of villages are being formed or have been formed in the hollow villages, the phenomenon of "hollow villages", hollow centers, and disorderly expansion of the periphery of villages are common in rural China. This article takes the site consolidation of hollow villages in mountainous and hilly areas as an example. It mainly introduces the irrigation and drainage engineering technology after the hollow village is rehabilitated to cultivated land, and provides scientific basis for water source protection and sustainable use of cultivated land.
\end{abstract}

Keywords: Mountainous and hilly area, Hollow village, Site consolidation, Water source project

\section{Introduction}

With the increase of non-agricultural transfer and employment of rural population, the demand for rural housing continues to grow. With the absence of rural construction planning and the absence of strict land management, hollow villages have been formed in which new house construction is expanding outside the village and idle in the village [1] The emergence of hollow villages is the result of a degraded evolution of the rural area system during the period of rural economic and social transformation and development, resulting in the waste and inefficient use of rural land resources, seriously hindering the sustainable development of rural economic society and causing land resources. Serious damage and waste [2][3].

In order to effectively use the idle land, after the hollow village is rehabilitated to cultivated land, the design of the water source project in the irrigation and drainage project is indispensable. The following are the pond and reservoir engineering, small barrage (gate),

Article history:

Received (December 25, 2019), Review Result (February 3, 2020), Accepted (March 16, 2020) 
mechanical (electric) well engineering, and rainwater collection. The design of these four types of projects is briefly explained [4][5].

\section{Water source engineering}

\subsection{Tangku project}

The construction scale of the pond storage project is $1,000 \sim 100,000 \mathrm{~m}^{3}$, and the level of the pond storage can be divided into two types: small type I pond storage and small type II pond storage. The small type I pond storage is $10,000 \sim 100,000 \mathrm{~m}^{3}$ and small type II pond storage. The volume is $1000 \sim 10,000 \mathrm{~m}^{3}$. The primary and secondary buildings of the Tangku project's hydraulic structures are all Grade 5 [6][7][8]. The pond reservoir project is suitable for mountainous and hilly areas with scattered irrigation areas and less, or plains, river valleys, and areas with a small amount of arable land distributed along the stream bed of the stream. A relatively narrow river valley, with good geological conditions, no seepage and leakage, and a certain water storage capacity. The upstream vegetation is better, with a certain area of rainwater collection, flood diversion or spring water, and an address closer to the planned irrigation area. The construction of the Tangku project should be adapted to local conditions and local materials should be selected. The selection of Chengba type is based on local building materials. Earth dams are used in areas with extensive storage of earth materials. Earth and rock can be used in areas where there is mutual soil. Stone-filled dams should be used in areas rich in stone. According to the storage and quality of earth materials, earth dams can be divided into homogeneous earth dams or clay core walls (Oblique) dam. In the extensive storage of soil materials, the soil quality is better, and homogeneous earth dams can be selected. If most of the soil is poor, clay core wall (sloping) dams can be selected. The masonry stone can be a gravity dam or an arch dam. The masonry gravity dam is adapted to the general terrain. The arch dam must be built on a narrow, symmetrical, and good geological river bed. The dam project of the Tangku project must be established after comparing with the earth dam and the masonry stone dam scheme.

\subsection{Small barrage (Gate)}

The dam site of the river dam (slug) should be selected in a place with good geological conditions, the river bed and the bank rocks on both sides of the bank exposed, the slopes on both banks stable, and the river surface wide. The construction of the dam should make full use of local water resources, and if conditions permit, the dam site should be selected at the section below the intersection of the two small rivers. The layout of the dam axis should be perpendicular to the mainstream of the riverbed, and the choice of dam type should match the local building materials. The type of dams for river diversion and overflow are generally masonry and concrete dams. Due to the poor geology of the riverbed, the river flow is large and the water diversion flow is small. Rockfill dams or pile dams (pile rock in the middle) can be used. The diversion overflow dam adopts stone masonry or concrete structure, and the section of the dam body mostly adopts two types of wide top weir or practical weir. For those with higher barrage dams and larger water flow, in order to reduce the overflow length of the dam body, a practical weir type is adopted. For lower barrage dams, a wide roof weir type is adopted for the convenience of construction. Overflow dams generally use mortar-stone or concrete structures. The type of building dam is a practical weir or wide roof weir. The structure calculation is the same as that of pond-rock and concrete dams in the reservoir engineering. The sloping surfaces of the riverbed on both sides of the dam must be equipped 
with water-guide wing walls. The length of the upstream should not be less than $3 \mathrm{~m}$, and the length of the downstream is the same as that of the stilling pond. According to the engineering geological conditions, gravity slope protection or gravity retaining wall can be set, using mortar stone or concrete structure; the height of the wall top is the design water level plus $0.3 \mathrm{~m}$; when the slope of the river bank is more stable, the slope protection is built and the slope protection structure is large The roof is small, and the thickness should not be less than $0.3 \mathrm{~m}$. When the slope stability on both sides of the river bed is poor, set up retaining walls. The cross section should be $0.4 \mathrm{~m}$ in width, one side is vertical, and the slope ratio is 1 : 0.3 to $1: 0.4$. Should be less than $0.5 \mathrm{~m}$ and set drainage holes.

\subsection{Mechanical (Electric) well engineering}

Well irrigation is suitable for areas where surface water is scarce, groundwater is abundant, and burial depth is within $40 \mathrm{~m}$. The water filtering structure should have sufficient strength and water inlet area. To solve the irrigation problem of scattered high ground or surface water in mountainous and hilly areas, the minimum water output of a single well should be not less than $50 \mathrm{~m}^{3} / \mathrm{h}$. When the entire mountainous and hilly area requires groundwater for irrigation, the water output of a single well should not be less than $100 \mathrm{~m}^{3} / \mathrm{h}$. The irrigation area of a single well should be controlled. In addition to being able to run into the well wall and water filter pipe, the diameter of the wellbore should also meet the requirements of the surrounding filter material. When using a non-gravel filter, it should be larger than $100 \mathrm{~mm}$. When using a gravel filter, the medium and coarse sand aquifers should be larger than $200 \mathrm{~mm}$, and the fine and fine sand aquifers should be larger than $300 \mathrm{~mm}$. The top of the filter material to the wellhead section is closed with clay balls or blocks for $3 \sim 5 \mathrm{~m}$, and the remaining part can be filled with clay. Around the wellhead, general clay compaction can be used within a depth of $20 \mathrm{~m}$, and the thickness should be not less than $200 \mathrm{~mm}$. The depth of the well between 20 and $40 \mathrm{~m}$ can be closed with clay balls or cement slurry, and the thickness should not be less than $300 \mathrm{~mm}$. According to the depth of the well wall pipe and water filter pipe, steel pipes, cast iron pipes, reinforced concrete pipes, plastic pipes, concrete pipes, sandless concrete and other pipes are selected. The appropriate depth of various pipes shall meet the requirements of [Table 1]. Sandless concrete pipes, concrete pipes, and reinforced concrete pipes are implemented in accordance with SL / T154-95 "Welded Steel Pipes" and GB / T3244-87 "Continuous Cast Iron Pipes".

Table 1. The suitable depths for various pipes

\begin{tabular}{|c|c|c|c|c|c|c|}
\hline Pipe type & Steel Pipe & $\begin{array}{c}\text { Cast iron } \\
\text { pipe }\end{array}$ & $\begin{array}{c}\text { Reinforced } \\
\text { concrete pipe }\end{array}$ & $\begin{array}{c}\text { plastic } \\
\text { pipe }\end{array}$ & $\begin{array}{c}\text { Concrete } \\
\text { pipe }\end{array}$ & $\begin{array}{c}\text { Sandless concrete } \\
\text { pipe }\end{array}$ \\
\hline Suitable depth & $>400$ & $200 \sim 400$ & $150 \sim 200$ & $\leq 50$ & $\leq 50$ & $\leq 50$ \\
\hline
\end{tabular}

*Note: The reinforced concrete pipe is constructed by welding, lifting, and floating board installation. The suitable experiment is $200 \sim 400 \mathrm{~m}$.

\subsection{Rainwater storage project}

Because it is difficult to form a large area of irrigation in mountainous and hilly areas, rainwater collection is particularly important. The rainwater storage related work is performed in accordance with the standard GB / T50363-2006 "Technical Specifications for Watersaving Irrigation Engineering". Show the area of rainwater collection and collection shall be calculated and determined according to the design irrigation guarantee rate, corresponding 
annual precipitation, and collection coefficient and irrigation area. The volume of rainwater storage project can be determined according to the annual water supply, evaporation and leakage in different areas in [Table 2].

Table 2. Number and quota of rainwater harvesting for different crops

\begin{tabular}{|c|c|c|c|c|}
\hline \multirow{2}{*}{ Crop } & \multirow{2}{*}{ Irrigation method } & \multicolumn{2}{|c|}{ Number of irrigations at different rainfalls } & \multirow{2}{*}{$\begin{array}{c}\text { Irrigation } \\
\text { quota }\left(\mathrm{m}^{3} / \mathrm{hm}^{2}\right)\end{array}$} \\
\hline & & $250 \sim 500 \mathrm{~mm}$ & $>500 \mathrm{~mm}$ & \\
\hline \multirow{5}{*}{$\begin{array}{c}\text { Dry crops such as } \\
\text { corn }\end{array}$} & Sitting water & 1 & 1 & $45 \sim 75$ \\
\hline & Spot irrigation & $2 \sim 3$ & $2 \sim 3$ & $75 \sim 90$ \\
\hline & Plastic film irrigation & $1 \sim 2$ & $1 \sim 2$ & $45 \sim 90$ \\
\hline & Water irrigation & $2 \sim 3$ & $1 \sim 2$ & $30 \sim 60$ \\
\hline & $\begin{array}{c}\text { Drip irrigation } \\
\text { Plastic ditch irrigation }\end{array}$ & $1 \sim 2$ & $2 \sim 3$ & $150 \sim 225$ \\
\hline \multirow{3}{*}{ Season vegetables } & Drip irrigation & $5 \sim 8$ & $6 \sim 10$ & $120 \sim 180$ \\
\hline & $\begin{array}{l}\text { Micro sprinkler } \\
\text { irrigation }\end{array}$ & $5 \sim 8$ & $6 \sim 10$ & $150 \sim 180$ \\
\hline & Spot irrigation & $5 \sim 8$ & $8 \sim 12$ & $75 \sim 90$ \\
\hline \multirow{4}{*}{ Fruit tree } & Drip irrigation & $2 \sim 5$ & $3 \sim 6$ & $120 \sim 150$ \\
\hline & $\begin{array}{c}\text { Tubule outflow } \\
\text { irrigation }\end{array}$ & $2 \sim 5$ & $3 \sim 6$ & $150 \sim 225$ \\
\hline & $\begin{array}{l}\text { Micro sprinkler } \\
\text { irrigation }\end{array}$ & $2 \sim 5$ & $3 \sim 6$ & $150 \sim 180$ \\
\hline & $\begin{array}{l}\text { Spot irrigation (hole } \\
\text { irrigation) }\end{array}$ & $2 \sim 5$ & $3 \sim 6$ & $150 \sim 180$ \\
\hline One season rice & $\begin{array}{l}\text { "Thin, shallow, wet, } \\
\text { sun" and controlled } \\
\text { irrigation }\end{array}$ & - & $6 \sim 9$ & $300 \sim 400$ \\
\hline
\end{tabular}

\section{Water delivery project}

\subsection{Open channel}

Open channel water transfer is suitable for farmland irrigation, flood prevention and drainage, power generation and water diversion projects other than poor geological conditions, 
water transport projects that passthrough villages and towns, urban areas, and water sources for humans and animals.

It is advisable to set up fixed water supply channels in the order of four levels: stem, branch, bucket and agriculture. The area of small irrigated area can reduce the number of channels. Generally, it should not be less than two fixed channels. Channels at all levels should choose higher terrain within their control. It has been demonstrated that local highland magpies within the artesian range can be used for irrigation.

\subsection{Pipeline}

According to the method of water distribution and distribution, it can be divided into a water lifting and conveying system and a self-pressure water conveying system. The water lifting and conveying can be divided into a pump direct delivery type and a reservoir type. The pipeline system in the area around the well is mostly direct-pumped by water pumps. Spray and micro-spray irrigation are pumps that send water to sprinklers for micro-irrigation. The self-pressure water delivery system is an artesian irrigation project that uses the water level difference between the water source and the required water area.

The layout of the water pipeline should avoid passing through ponds, ditches, houses, and cemeteries, and the planar layout of the water pipeline should be as straight as possible; the longitudinal section changes smoothly, and the convenient lines are selected for construction, transportation and management.

Buried pipes: Plastic pipes must be buried; cement prefabricated pipes and steel pipes can be buried or placed on the ground, and should be compared and determined from the convenience of management irrigation. The buried depth of the pipeline shall be no less than $0.6 \mathrm{~m}$ below the ground, and the excavation width of the pipe groove shall be convenient for engineering construction and installation. For pipes with larger pipe diameters, the groove bottom width should be 20 to $30 \mathrm{~cm}$ plus the large end of the pipe. The excavation slope is calculated as 1: 0.25 . For smaller pipes, the working surface required for manual trenching should be determined. Not less than $30 \sim 40 \mathrm{~cm}$.

\subsection{Ground irrigation}

Irrigation ditch, length, ditch ratio, and ditch flow are determined according to soil water permeability and planned field length and short sides. Soil water permeability is greater than $0.15 \mathrm{~m} / \mathrm{h}$, trench length is 30 to $100 \mathrm{~m}$, specific drop is less than $1 / 500$ and greater than $1 / 200$, and flow into the trench is 0.7 to $1.5 \mathrm{~L} / \mathrm{s}$; soil water permeability is 0.1 to $0.15 \mathrm{~m} / \mathrm{h}$, trench length is $40 \sim 100 \mathrm{~m}$, specific drop is less than $1 / 500$ and greater than $1 / 200$, and the flow into the ditch is $0.4 \sim 1.0 \mathrm{~L} / \mathrm{s}$; soil permeability is less than $0.1 \mathrm{~m} / \mathrm{h}$, and the ditch length is $60 \sim 150 \mathrm{~m}$, and the specific drop is less than 1/500 and greater than 1/500 200, into the trench flow $0.2 \sim 0.6 \mathrm{~L} / \mathrm{s}$.

\section{Spray micro irrigation and drainage engineering}

The sprinkler irrigation project is used to irrigate areas where water resources are scarce, or areas where economic crops, fruits, and vegetables are concentrated, and the areas are more economically developed. Sprinkler irrigation is divided into pipeline sprinkler irrigation system and unit type sprinkler irrigation system. According to its main structure, the pipeline sprinkler irrigation system is divided into fixed and semi-fixed, and the unit type sprinkler irrigation system is divided into fixed spray and mobile. The sprinkler irrigation system 
consists of water source engineering, the first hub, pipe network system and sprinkler head. Water from ponds, reservoirs, wells and canals can be used as sources of sprinkler irrigation. The first hub consists of power equipment, water pumps, filters, fertilizer applicators, pressure relief valves, water meters and so on. The pipe network is composed of water pipes of different specifications and corresponding connecting pipes, valves and other equipment.

There are various types of land in mountainous and hilly areas, and different textures have different sprinkler irrigation strengths. Refer to GB 50085-2007 "Technical Specifications for Sprinkler Irrigation Engineering". See [Table 3] for the allowable sprinkler irrigation strength of different texture soils. See [Table 4] for the allowable reduction of spray irrigation intensity on sloping fields. Micro-irrigation system is divided into drip irrigation, microsprinkler irrigation, small tube outflow and so on. Drip irrigation and small tube outflow are suitable for fruit trees and cotton irrigation. Micro sprinkler irrigation is suitable for irrigation of vegetables, flowers, lawns and other cash crops. The micro-irrigation system usually consists of water source engineering, the first hub, the water distribution network and the irrigation device.

Table 3. Allowable spray irrigation intensity for various soils

\begin{tabular}{|c|c|c|c|}
\hline Soil type & $\begin{array}{c}\text { Allowable sprinkler } \\
\text { intensity }(\mathrm{mm} / \mathrm{h})\end{array}$ & Soil strength & $\begin{array}{c}\text { Allowable sprinkler } \\
\text { intensity }(\mathrm{mm} / \mathrm{h})\end{array}$ \\
\hline sand & 20 & Loam clay & 10 \\
\hline Sandy loam & 15 & Clay & 8 \\
\hline Loam & 12 & & \\
\hline
\end{tabular}

Table 4. Reduced allowable sprinkler intensity on slopes

\begin{tabular}{|c|c|c|c|}
\hline Ground slope (\%) & $\begin{array}{c}\text { Allowable sprinkler } \\
\text { intensity (\%) }\end{array}$ & Ground slope (\%) & $\begin{array}{c}\text { Allowable sprinkler } \\
\text { intensity (\%) }\end{array}$ \\
\hline $5 \sim 8$ & 20 & $13 \sim 20$ & 60 \\
\hline $9 \sim 2$ & 40 & $>20$ & 75 \\
\hline
\end{tabular}

The open drainage drainage project can be provided with a fixed drainage channel in accordance with the order of four levels: trunk ditch, branch ditch, bucket ditch, and agricultural ditch. Temporary drainage ditches such as furrows should be arranged below the agricultural ditch in areas with frequent floods and waterlogging. The three levels of dry, branch, and bucket are water conveyance networks, the agricultural ditch is the final fixed drainage ditch, and the agricultural ditch and hairy ditch are field catchment networks. New fixed drainage ditch for new drainage works in mountainous and hilly areas should not exceed three levels. It is suitable for drainage projects above the final fixed drainage ditch with selfdrainage conditions in high-efficiency economic crop areas, and Chuandao paddy field drainage projects with smaller areas and large terrain ratios in the southern Shaanxi hilly area. The combination of light and dark should be adopted. Concealed pipe drainage should adopt single-stage drainage or double-stage drainage system according to local conditions. Singlestage concealed pipe drainage, only the field is equipped with suction pipes. Each suction pipe has a water outlet to drain water into the open ditch. The double-stage concealed pipe drainage system consists of a suction pipe and a water collecting pipe. Water suction pipes are 
arranged in the field to discharge water into the water collection pipes, which are then merged into the open ditch or drainage area.

\section{Conclusion}

This article explains the design elements of the irrigation and drainage sub-projects, and provides a technical reference for the renovation of hollow villages and cultivated land. In mountainous and hilly areas, its water source projects are mainly ponds and reservoirs, which can vigorously develop rainwater storage projects; according to the cost of the project, the water conveyance project can be reasonably selected, and canals can be laid for pipes. Where conditions permit, it can be directly carried out on the ground. Irrigation; and micro-irrigation and drainage works can be carried out according to the type of cultivated land under renovation.

\section{References}

[1] Y. S. Liu, H. L. Long, and Y. F. Chen, "The rural development research report: rural hollowing and its remediation strategies in China," Beijing: Science Press, (2011)

[2] L. Xue, "Discussion on the "Hollow Village" Phenomenon and Countermeasures in the Background of Urbanization: Take Jiangsu Province as an example,” City Planning, vol.25, no.6, pp.8-13, (2001)

[3] L. S. Cheng, W. Y. Feng, and L. H. Jiang, "The analysis of rural settlement hollowizing system of the southeast of Taiyuan basin," Acta Geographica Sinica, vol.56, no.4, pp.437-446, (2001) DOI: $10.11821 / x b 200104007$

[4] J. Li and X. J. Li, "The microscopic analysis on village-hollowing in medium income and hilly land region of Henan province," China Population , Resources and Environment, vol.18, no.1, pp.170-175, (2008) DOI: 10.3969/j.issn.1002-2104.2008.01.033

[5] S. H. Xu, "The integral reginmes and countermeasure study on hollow-oriented houses in rural regions," Territory \& Natural Resources Study, no.1, pp.11-12, (2004) DOI: 10.3969/j.issn.1003-7853.2004. 01.006

[6] Y. Zhang, Q. Q. Rui, S. C. Liu, and W. F. Zheng, "Study on the development model of hollow village combining rural health and recreation industry under the background of rural revitalization," journal of Heilongjiang vocational institute of ecological engineering, vol.33, no.1, pp.75-78, (2020) DOI: 10.3969 /j.issn.1674-6341.2020.01.022

[7] X. L. Zhang, "Current situation and countermeasures of precision poverty alleviation in "hollow villages" in guangxi minority regions under the background of rural rejuvenation," Journal of Rural Scientific, no.12, pp.40-41, (2019) DOI: 10.19345/j.cnki.1674-7909. 2019.35.018

[8] X. C. Wang, S. M. Yao, and C. H. Chen, "Empirical study on "village - hollowing" in China," Scientia Geographica Sinica, vol.25, no.3, pp.257-262, (2005) DOI: 10.3969/j.issn.1000-0690.2005. 03.001 
This page is empty by intention. 